lithic, the Tisza and the Lengyel culture, the territory of Hungary provided a series of finds of real canines but also imitations in bone and antler from funerary contexts. ${ }^{10}$ Interestingly, the imitations came mostly from women and unsexable children's graves (while the men's graves are reserved for a few exemplars of real canines), a relevant situation in this perspective being illustrated by the burials at the late Neolithic village site at Polgár-Csőszhalomdülö 6, in the north of the Great Hungarian Plain. ${ }^{11}$ There are several finds in the Balkan area also: at Durankulak, such ornaments seem to come from the graves of presumptive young men or boys. ${ }^{12}$ In the area of the AriuşdCucuteni-Trypillia cultural complex, red deer canines and their imitations in bone were found in the hoards at Ariuşd, Brad, Hăbăşeşti, Izvoare, Cărbuna and Chetroşica. ${ }^{13}$ A pendant from a Unio valve, imitating a canine, came from a Stoicani-Aldeni layer at the Suceveni-“Stoborăni" settlement. ${ }^{14}$

During the Bronze Age, such finds seem to become more rare, but they do not disappear altogether. A perforated red deer canine was among the grave goods in burial no. 8 of the Monteoru necropolis at Năeni (Buzău), found under the legs of the deceased. ${ }^{15}$ Another similar object came from the nearby settlement at Năeni- "Zănoaga" Cetatea 2, from an Early Monteoru cultural layer. ${ }^{16}$ Two perforated canines came from the eponymous site of the Bronze Age Costişa culture (Neamț County), one connected to Costişa culture archaeological layer and another to an unknown context. ${ }^{17}$ Further west, a perforated real deer canine bead was found in the Middle Bronze Age site of Százhalombatta, Hungary (personal communication Alice M. Choyke, 2019).

Thus, it appears that in South-Eastern Europe, our area of interest, such ornaments (real red deer canines or imitations) were highly popular and widespread, especially during the final Late Neolithic, Eneolithic and the beginning of the Bronze Age. ${ }^{18}$ During the later periods, these type of ornament became increasingly rare.

The main aim of this paper is to present and consider the implications of a unique find from Valea Stânii necropolis (Romania): a set of 16 personal ornaments made of red deer antler, all burnt and therefore mostly fragmented, imitating the shape of red deer canines. The assemblage presented in this study is not the only one known within the Ferigile cultural milieu $\left(7^{\text {th }}-5^{\text {th }}\right.$ centuries BC) of the Early Iron Age, however this is the last appearance of its kind in the prehistory of the Lower Danube.

Among other rather late artefacts known so far is a find documented in Central-Eastern Europe at the dawn of the Iron Age: a set of eight perforated red deer canines found in tomb no. 37 (probably the grave of an adult male) at Füzesabony-“Kettőshalom" (Hungary), attributted to the pre-Scythian horizon Füzesabony-Mezőcsát, ${ }^{19}$ dated ever so slightly before the cultural context of the imitations from Valea Stânii.

Similarly to the Ferigile group, to date, personal ornaments made of deer canines or their imitations did not appear in the neighboring cultural groups to the north and west, such as the Ciumbrud group in Transylvania and the Alföld group in the Great Hungarian Plain, although pendants made of perforated animal (not deer but wolf, bear or dog) teeth ${ }^{20}$ were recovered from a variety of contexts. A single pierced ("probably red deer") canine was discovered in a grave part of the "Scythian Age" necropolis at Tiszalök (Hungary) ${ }^{21}$ attributed to the Alföld group, and thus, somewhat contemporaneous with (or slightly later than) the necropolis at Valea Stânii. Interestingly, the adult woman buried there had the physical charcacteristics (anthropologically) of the pre-Scythian population belonging to the Mezőcsát group. ${ }^{22}$ In the early Scythian graves north of the Black Sea, perforated teeth of various animals were sometimes used as pendants. ${ }^{23}$ Red deer canine beads were not among them, however, suggesting they had no special cultural significance in this region.

However, solid analogies are found much further to the East, among the nomadic populations of southern Siberia (at Tuva especially). During the $8^{\text {th }}-6^{\text {th }}$ centuries BC the pendant beads were made of pierced Siberian maral ("New World elk"; Cervus elaphus sibiricus) teeth appear as a distinctive cultural pattern. ${ }^{24}$ In this wide area, several

2010.

${ }^{10}$ BÁNFFY 2008; CHOYKe 2010.

${ }^{11}$ SiKLÓsi 2004; BÁNFFY-BognÁR-KutZIÁn 2007; CHOYKE

12 TODOROVA 2002

${ }^{13}$ Monah 2003; Beldiman-SzTancs 2008.

${ }^{14}$ BELDIMAN et al. 2012.

${ }^{15}$ VulPE-DrÂMBOCIANU 1981, 177, fig. 9/4.

${ }^{16}$ MĂRGĂRIT et al. 2011.

${ }^{17}$ MĂRGĂRIT-DuMITRAȘCU 2017.

${ }^{18}$ It should be noted that at the level of absolute data, what is considered Chalcolithic in the Balkans is still Late Neolithic in Hungary and even Middle Neolithic in Western Europe.

Acta Archaeologica Academiae Scientiarum Hungaricae 70, 2019
${ }^{19}$ PATeK 1990, 63, Taf. 10/5-12.

${ }^{20}$ Marinescu 1984, 61, Abb 10/7; KemencZei 2009, 93, 186, list 9, Taf $1 / 5,64 / 11$.

${ }^{21}$ Scholtz 2012, 78, 88, pl. 4/8

${ }^{22}$ SZATHMÁRY 2012, 101.

${ }^{23}$ ILINSKAJA 1968, pl. 12/7, 22; 27/44-47; 34/12, 14; PetrenKo 1978, pl. 23/28; 25/5.

${ }^{24}$ Mannai-Ool 1970, 97; Čugunov 2005, 67-69, fig. 3/5; 
finds in necropolises such as the one from Bai-Dag I attributed to the Aldy-bel culture (Early Scythian Period) seem to convincingly suggest that canines of musk deer (Moschus moschiferus) and other teeth of Siberian deer (maral) with drilled round holes are an attribute of female burials. ${ }^{25}$ The drilled maral deer canines appear as part of the rich assemblage of the "royal" grave (the grave no. 5) in the Arzhan-2 kurgan (the $7^{\text {th }}$ century BC), as indicated by the items exhibited at the Hermitage Museum in Sankt Petersburg. ${ }^{26}$ Not without significance is the fact that the socalled deer stelae ("olennye kamni") with realistically engraved images of deer, maral, and elk are also very com$\mathrm{mon}^{27}$ in this large South Siberian area, from Tuva to Mongolia, usually in connection with graves similar to those mentioned above.

\section{ARCHAEOLOGICAL CONTEXT}

The context of the present discovery is a funerary one, namely the cremation necropolis located in the south-central part of Romania, in the village of Valea Stânii, Argeş County. The site dates to the Early Iron Age and consists of ca. 35 small barrows covered with stone mantles ${ }^{28}$ (Fig. 1). The particularities of the rite and ritual, as well as the type of grave goods, connect this necropolis to the so-called Ferigile archaeological group. This particular Iron Age group ( $7^{\text {th }}-5^{\text {th }}$ centuries BC) is represented by a horizon of cremation necropolises of small barrows covered with stones, mostly located in the high sub-mountainous area of the Southern Carpathians. ${ }^{29}$

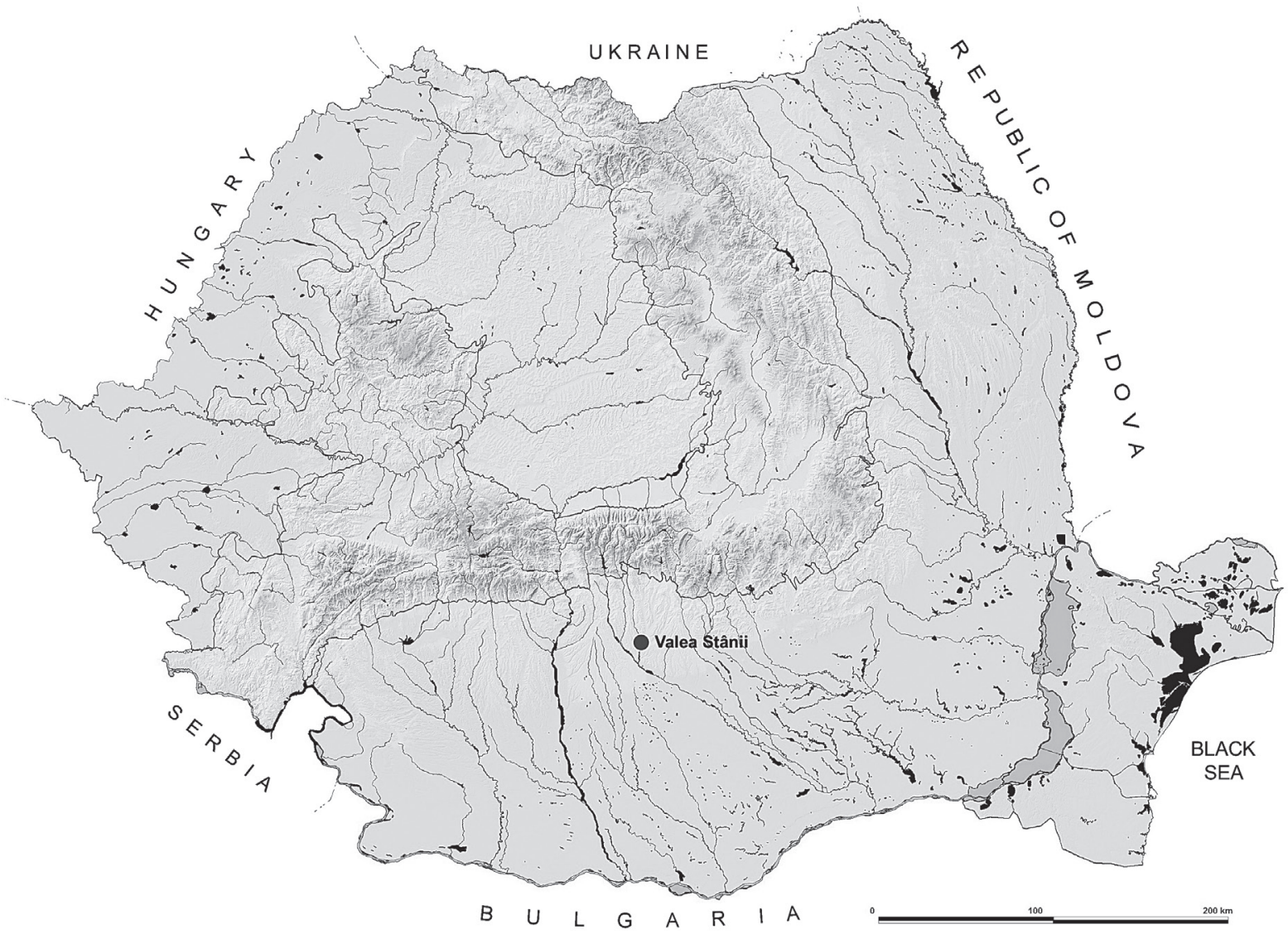

Fig. 1. Valea Stânii. Location of the archaeological site

${ }^{25}$ HudiaKov et al. 2013, 110.

26 "The Siberian Times" online, on 2016, February 11.

${ }^{27}$ GRYAZNOV 1980, 41, fig. 29; GRYAZNOV 1984.

\section{${ }^{28}$ MĂNDESCU 2016. \\ ${ }^{29}$ VULPE 1967}


These personal adornments made from antler were among the grave goods found in barrow no. 4 located at the northeastern edge of the necropolis (Fig. 2) explored during the 2015 archaeological season. This sealed context showed some distinctive and exciting features. Firstly, it was a double grave, where two distinct groups of cremated human bones were placed side by side, the first one belonging to an adult woman, 20-50 years old, and the second one belonging to a subadult individual, 15-20 years old, whose sex could not be established (Fig. 3). The cremated bones (burned at a temperature of above $800^{\circ} \mathrm{C}$, not on the spot, but on a pyre located somewhere else, in an unknown place) and the grave goods also showing obvious traces of burning, found at a depth of between $-0.3 \mathrm{~m}$ and $-0.5 \mathrm{~m}$ were deposited on the ancient occupational level or possibly in a slight depression of the ground. Everything was afterwards covered with a heap of river boulders of different sizes arranged into at least two layers,

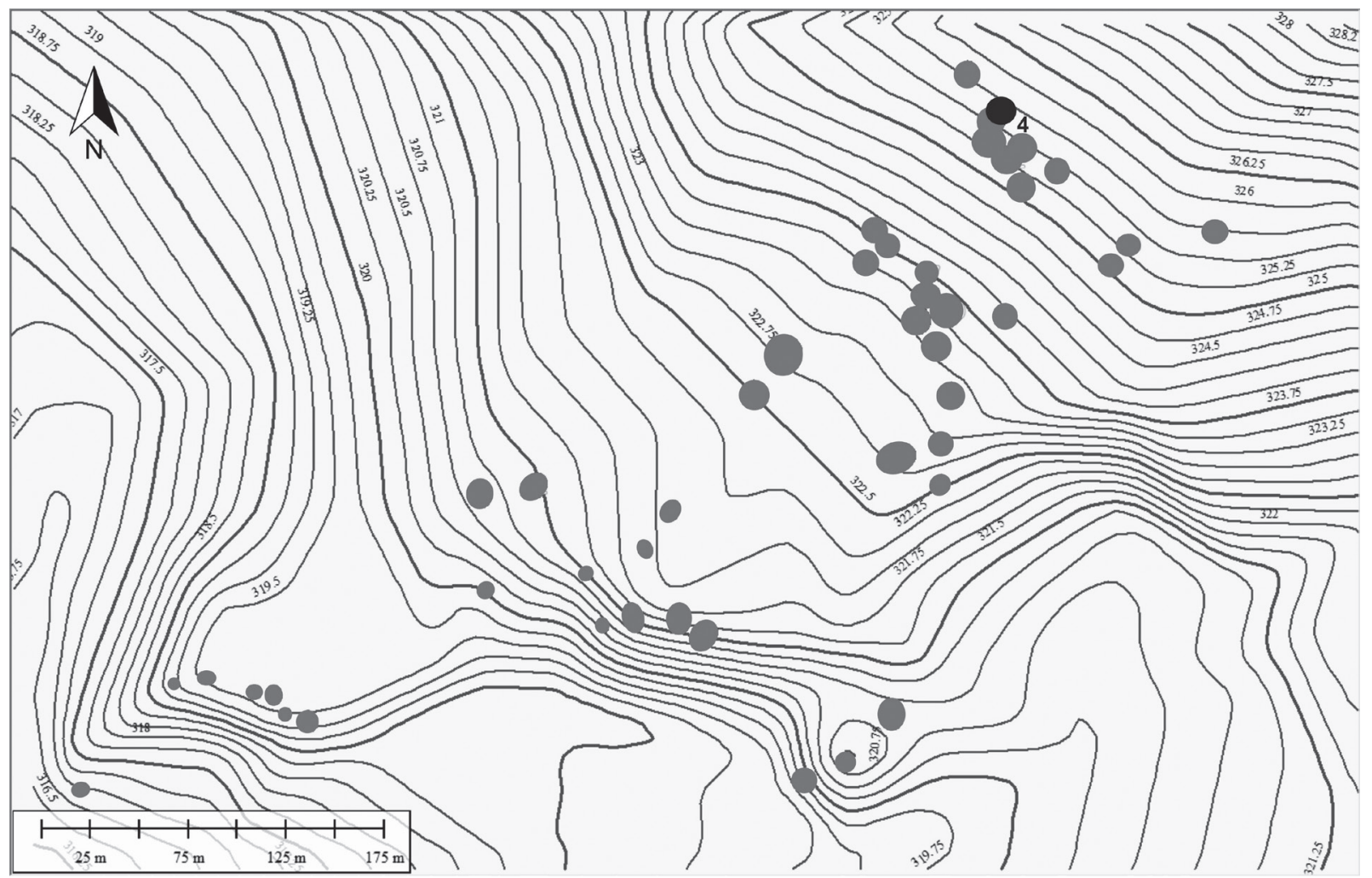

Fig. 2. Location of barrow no. 4 on Valea Stânii necropolis plan (2018 stage). Layout by D. Ştefan and D. Măndescu

resulting in a barrow (nowadays flattened by modern plowing) with a diameter of about $8 \mathrm{~m}$ (an average size for the necropolis at Valea Stânii). A large number of potsherds belonging to hand-formed vessels (storage vessels but also table-ware) displaying clear Ferigile stylistic features were deposited mainly in the center of the tumulus, in area of the grave, where they melted with the calcined bones and the grave goods artefacts. Vessel fragments were also found on the southern edges of the tumulus.

The personal ornaments, particularly hundreds of kaolin, clay and glass beads as well as fragments of shells were found together with the bones of the adult female. The kaolin beads, attested here for the first time for the Ferigile group, point towards some foreign but neighboring cultural milieu, since a high density of such kind of ornaments was widely documented in female graves of the contemporary Ciumbrud group in Transylvania. ${ }^{30}$ Among the calcined bones of the subadult individual a set of red deer canine imitations and some iron weapons (a double edged axe, knife, arrowheads, and a fragment possibly of a spearhead) were found. It is obvious that this subadult individual was given a warrior's burial, deliberate intenting a high status representation in the afterlife. Undoubtedly, the pair of individuals in the grave enjoyed great prestige within the community during their life, given the impres-

${ }^{30}$ MĂNDESCU et al. 2017. 


\begin{tabular}{c|c|c|c|c|}
$\begin{array}{c}\text { Individual } \\
\text { in the } \\
\text { grave of } \\
\text { barrow 4 }\end{array}$ & Sex & Age & $\begin{array}{c}\text { Cremated bones } \\
\text { Quantity }\end{array}$ & $\begin{array}{c}\text { Weight } \\
\text { (fragments) }\end{array}$ \\
\hline (grams)
\end{tabular}

Fig. 3. Anthropological identification of the two individuals buried in barrow no. 4 from Valea Stânii. Report by M. Constantinescu (after MăNDESCU et al. 2017, 24-25, tab. 1-2)

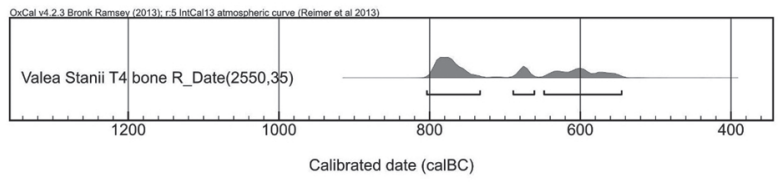

\begin{tabular}{|l|l|}
\multicolumn{1}{|c|}{$\begin{array}{c}\text { Sigma 1 } \\
\text { (probability 68.2\%) }\end{array}$} & \multicolumn{1}{c|}{$\begin{array}{c}\text { Sigma } 2 \\
\text { (probability 95.4\%) }\end{array}$} \\
\hline $799-751$ BC (44.3\%) & $804-734$ BC (48.5\%) \\
$683-668$ BC (8.2\%) & $690-662$ BC (11.2\%) \\
$636-626$ BC (4.0\%) & $649-546$ BC (35.7\%) \\
$614-591$ BC (11.6\%) &
\end{tabular}

Fig. 4. Radiocarbon data modelling of a sample (calcined human bone - Poz-86140) from Valea Stânii, barrow no. 4 and the calibrated ${ }^{14} \mathrm{C}$ age (after MĂNDESCU et al. 2017, 32-33, tab. 4, fig. 5)

sive amount of pottery found in this grave, the largest quantity in the entire necropolis (with potsherds from at least 35 ceramic vessels).

The absolute radiocarbon date of the grave (804-546 BC), obtained from a sample of calcined bone belonging to the subadult individual (Poz-86140), is neither very precise nor relevant as it falls within the so-called "Hallstatt Plateau". However, the most probable dating, suggested by the sigma 2 calibration, indicates a date preponderantly in the first half and the middle of the $8^{\text {th }}$ century BC (804-734 BC with a probability of 48.5\%) (Fig. 4). In any case, this period represents a date that is considerably earlier (by more than a century) than what was previously thought concerning the emergence of the Ferigile group, namely the mid- $7^{\text {th }}$ century $\mathrm{BC}$ at the earliest. ${ }^{31}$

\section{METHODOLOGY OF THE EXCAVATION, ANALYSIS OF THE HUMAN REMAINS AND THE STUDY OF PERFORATED ORNAMENTS}

\section{The archaeological excavations}

At the Early Iron Age necropolis of Valea Stânii began in 2014, and from 2015 onward this site has been part of the systematic annual archaeological research plan in Romania. The area of the necropolis is currently occupied by agricultural crops, which creates additional difficulties for archaeological research. No geophysical survey has yet been carried out at the site, so the excavations have focused directly on the barrows visible on the surface of the area and have also been guided by the evidence provided by the scattered river stones from the damaged barrow mantles, often uncovered and dispersed by plowing during the annual agricultural activities. The barrows were investigated individually using the altimetric method; the investigated area was divided into four (usually) or two square units of variable size according to the dimension of the mantle and aligned according to the cardinal points. A single one or two perpendicular balks of $0.5 \mathrm{~m}$ in width were preserved along the median area of the barrow. The vegetation layer was excavated manually by shovel, followed by the cleaning of the river stones that make

${ }^{31}$ VULPE 1990, 126. 
up the mantle by spatulas and brushes. After being documented the stones in the mantle were measured, drawn and photographed and the boulders were removed. The last stage was the excavation of the grave itself, also using spatulas and trowels. The size, position and relationship of the components of the funeral assemblage were measured and recorded in situ, then everything was extracted (ideally with as much surrounding soil as possible) and transported to the museum's laboratory in Piteşti ( $23 \mathrm{~km}$ away) for cleaning and primary restoration. The identification, extraction and cleaning of incinerated bones and small grave goods found between them took place in the laboratory and not on the site. This excavation methodology also pertains to the set of personal ornaments discussed here. When the research and documentation of the graves in the field was finished, for safety reasons, an of about $0.2 \mathrm{~m}$ thick band was excavated across the entire area of the square units in the upper natural layer. The excavation was finished at a depth of usually $0.70 / 0.75 \mathrm{~m}$. Next, the profiles within the stratigraphic column were documented using drawings and photos, after which the balks were gradually dismantled and investigated according to the method outlined above. After completing the excavation of each tumulus, the stones from the mantle were removed from the field and deposited along the fringes of the agricultural area, and the square units filled in flattened to re-enter the agricultural circuit.

\section{The human remains}

Were grouped according to the skeletal segments, counted and weighed using a digital scale. The intensity or the grade of combustion was estimated based on Wahl. ${ }^{32}$ Sex determination was done based on the available cranial and post-cranial features and measurements. ${ }^{33}$ Age was estimated using dental eruption and development, ${ }^{34}$ epiphyseal fusion, ${ }^{35}$ closure of the cranial sutures, ${ }^{36}$ and degenerative changes in the joints. ${ }^{37}$

\section{Technological and functional analysis of the red deer canine imitations}

Macroscopic and microscopic examination of the technological and use-wear traces present on the archaeological artefacts was undertaken. The location and character of these marks were systematically recorded. The burning process of the items destroyed most of the technological traces, so the macroscopic examination did not allow for the identification of the diagnostic elements which might have indicated how the raw material was processed. As a consequence, the microscopic analysis was essential for observing and recording any possible marks that survived the burning process. During the microscopic analysis, the artefacts were examined with a Keyence VHX-600 digital microscope (magnifications ranging from 30x to 150x); the images were taken using an embedded camera. Identification of possible areas with traces of use/deformation, in order to asses whether the items had been worn before being incorporated into the funeral inventory was achieved with an Olympus BX53M metallographic microscope (magnifications ranging from $100 \times$ to $200 \times$ ), equipped with an EOS 1200D Canon camera. Our interpretations were based on recent studies focusing on the manufacture and use of personal ornaments from Europe. ${ }^{38}$

\section{RESULTS}

The shape of these ornaments is similar to that of the Cervus elaphus canine. They have a globular bottom surface, and the edges of the initial blank were modified by elimination of the material in an attempt to thin the object. As a result the transversal section of the artefacts in the affected area varies between oval (eight pieces) to rectangular (seven pieces). At the medial level, the shape is convex-concave, with a narrowing section, becoming

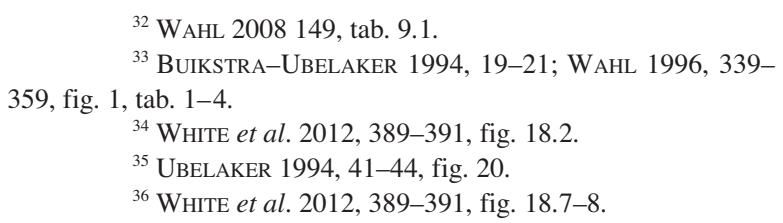

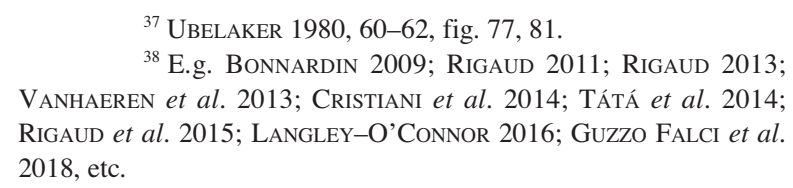

${ }^{38}$ E.g. Bonnardin 2009; Rigaud 2011; Rigaud 2013; VANHAERen et al. 2013; CRISTIANi $e t$ al. 2014; TÁtÁ et al. 2014 Rigaud et al. 2015; LANGLEY-O'ConNoR 2016; GuZzo FalCi et al. 2018, etc. 


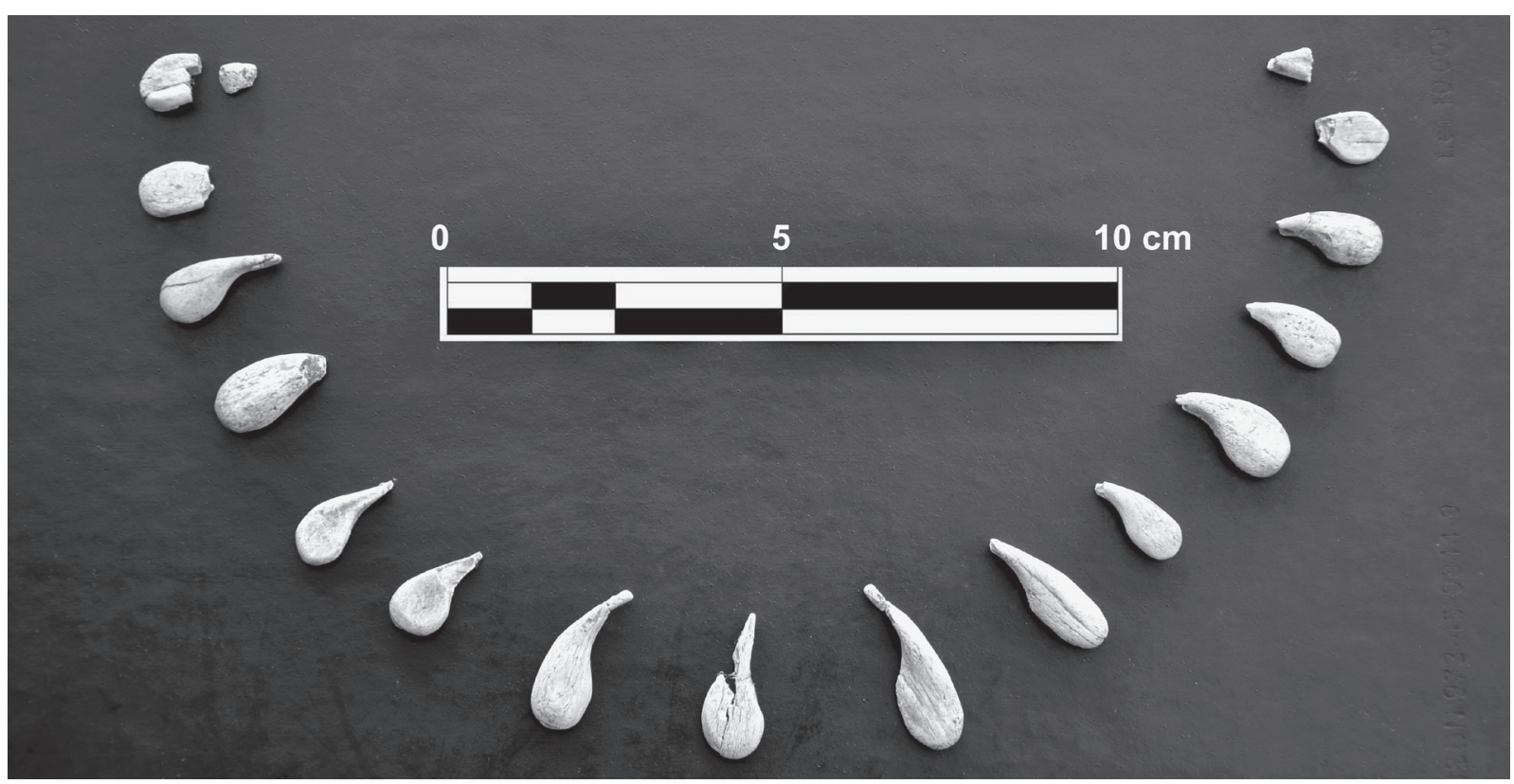

Fig. 5. Set of personal ornaments made of red deer antler imitating the shape of red deer canines from Valea Stânii, barrow no. 4. Photo D. Măndescu
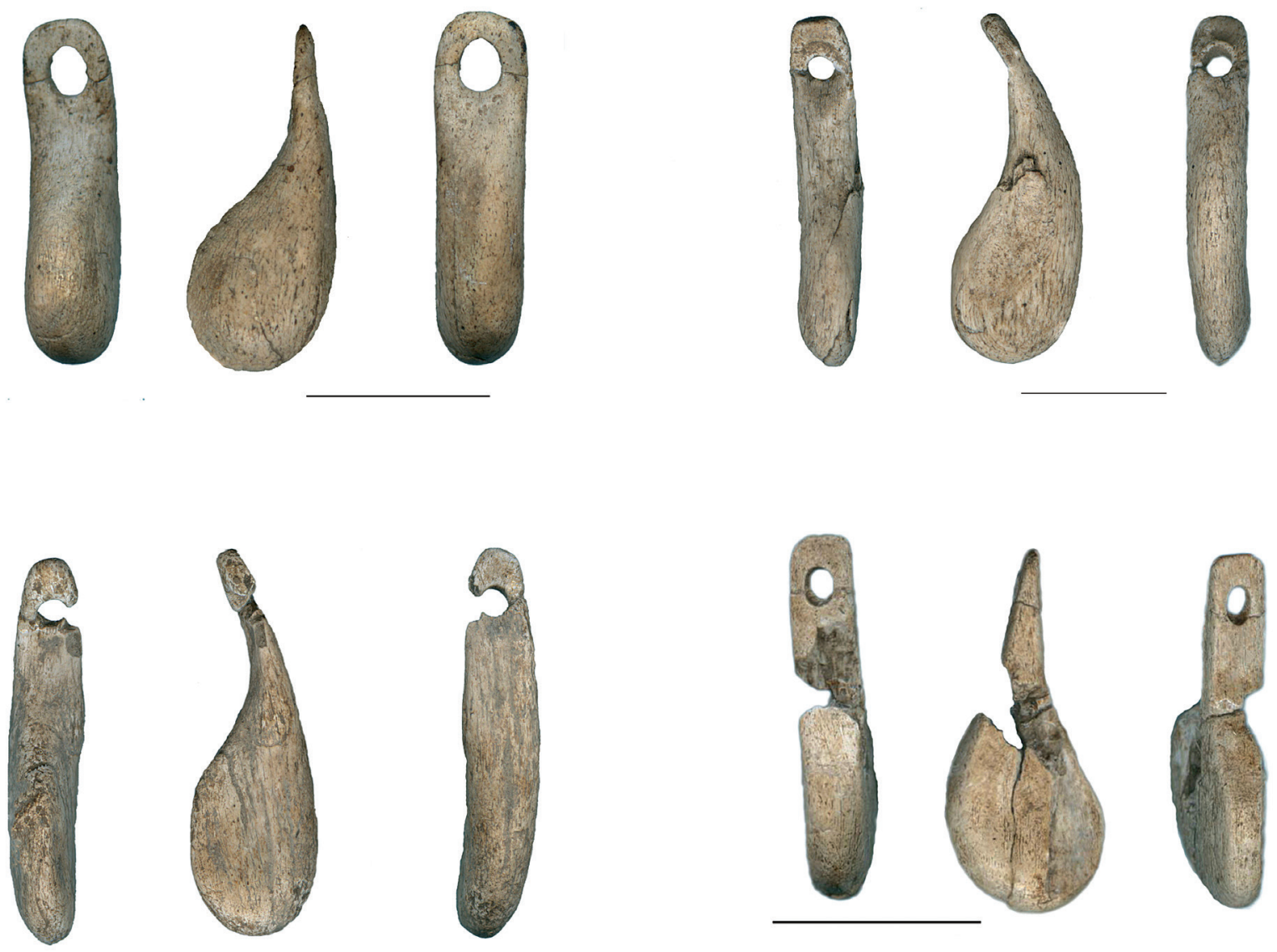

Fig. 6. Imitations of deer canines from Valea Stânii (best preserved objects). Photo M. Mărgărit 


\begin{tabular}{|c|c|c|c|c|c|}
\hline $\begin{array}{c}\text { Copy } \\
\text { no. }\end{array}$ & Lenght & $\begin{array}{c}\text { Maximum } \\
\text { width }\end{array}$ & $\begin{array}{c}\text { Minimum } \\
\text { width }\end{array}$ & Thickness & $\begin{array}{c}\text { Diameter of } \\
\text { perforation }\end{array}$ \\
\hline $\mathbf{1}$ & 18 & 7 & 0.8 & 4 & 1.8 \\
\hline $\mathbf{2}$ & 21.8 & 7.2 & 1.1 & 3.8 & 1.6 \\
\hline $\mathbf{3}$ & 22.4 & 6.8 & 0.9 & 2.8 & - \\
\hline $\mathbf{4}$ & 19.8 & 9.8 & 0.6 & 3 & 1.6 \\
\hline $\mathbf{5}$ & - & 6 & - & 3 & - \\
\hline 6 & - & 6.5 & - & 3 & - \\
\hline $\mathbf{7}$ & - & 6.5 & - & 5 & - \\
\hline $\mathbf{8}$ & - & 8.5 & - & 3 & - \\
\hline 9 & - & 8 & - & 5 & - \\
\hline 10 & - & 6.8 & - & 2.3 & - \\
\hline 11 & - & 7 & - & 2 & - \\
\hline 12 & - & 7 & - & 2.6 & - \\
\hline 13 & - & - & - & 2.2 & - \\
\hline 14 & - & 7.2 & - & 3 & - \\
\hline 15 & - & 7 & - & 2.4 & - \\
\hline 16 & - & 7.5 & - & 2.4 & - \\
\hline
\end{tabular}

Fig. 7. Morphometry of the imitations of deer canines (all dimensions in millimeters). Measurements by M. Mărgărit

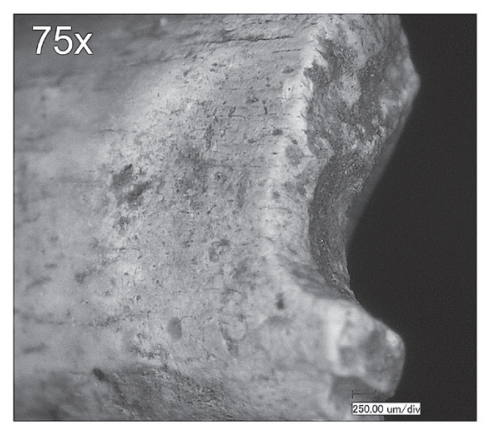

a

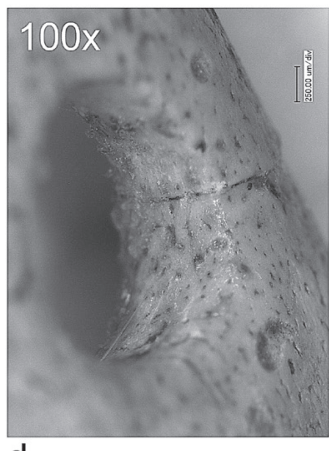

d

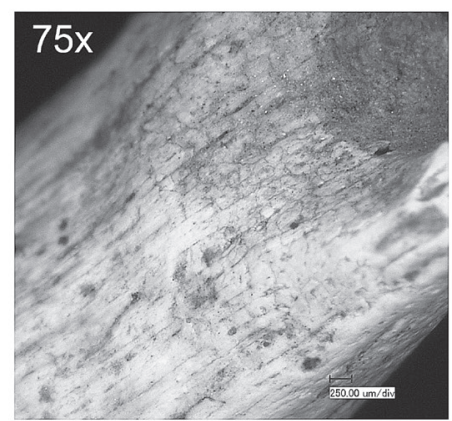

b

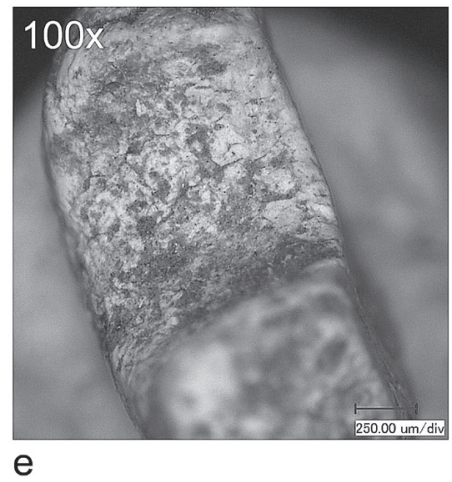

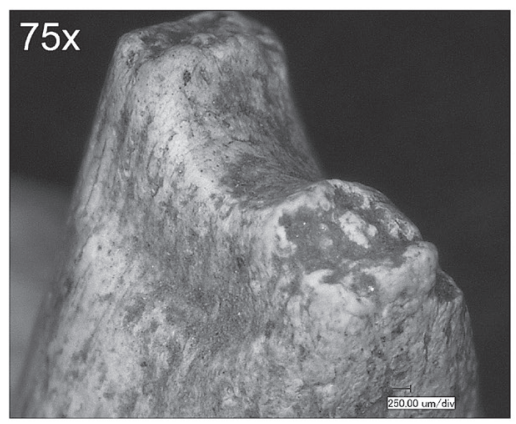

$\mathrm{C}$

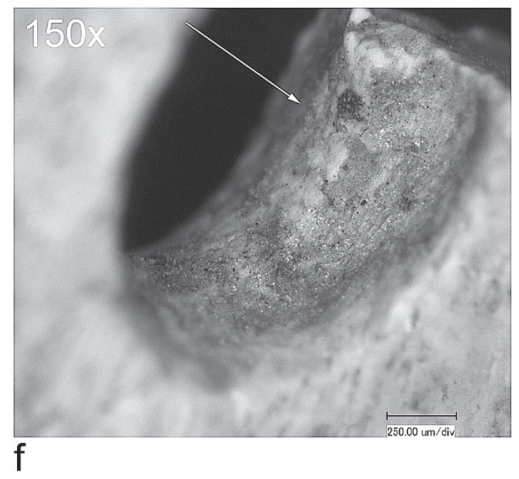

Fig. 8. Details of technological marks. a-c: surface preparated by scraping; d: perforation detail; e: perforation by unifacial rotation; f: perforation by bifacial rotation. Photo by M. Mărgărit 
rectangular at the distal level. A circular perforation with either a cylindrical (two pieces) or a biconical (nine pieces) section was made on each artefact. The perforation remained intact only on three items. The distal extremity, when preserved, has a convex or rectangular morphology. All the pieces were burnt on the funeral pyre, becoming creamcoloured (Figs 5-6).

Although their shape is standardized, their dimensions varies significantly: $18-22.4 \mathrm{~mm}$ in length, $6-8.5 \mathrm{~mm}$ in width, and $2-5 \mathrm{~mm}$ in thickness. The diameters of the preserved perforations range from 1.6 to $1.8 \mathrm{~mm}$ (Fig. 7).

From the beginning of our study it was obvious that we would not be able to reconstruct the complete technical process that led to obtaining the blank from the raw material block, primarily because the artefacts had been burnt, and secondly because the shaping operation destroyed the marks of the debitage operation. ${ }^{39}$ At the distal level, the area to be perforated was thinned by bifacial longitudinal scraping ${ }^{40}$ (Fig. 8a-c). During the next

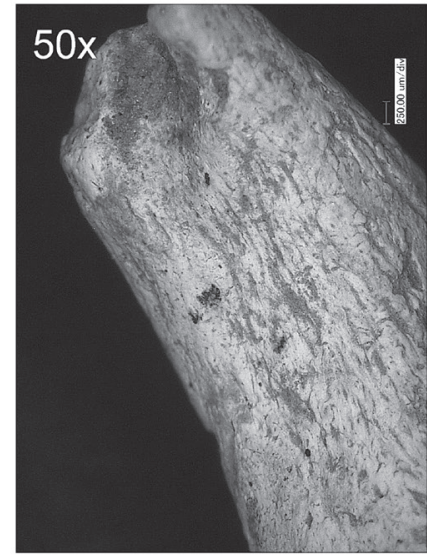

a

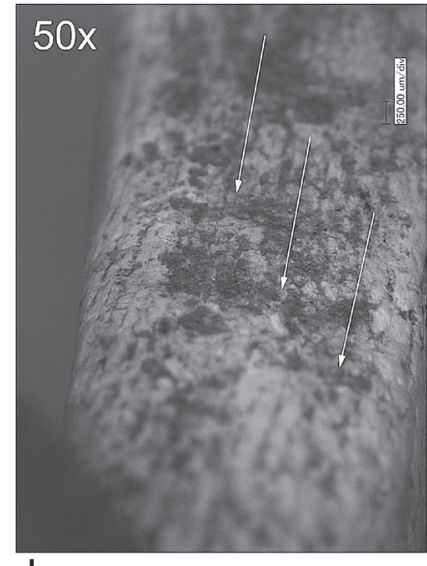

d

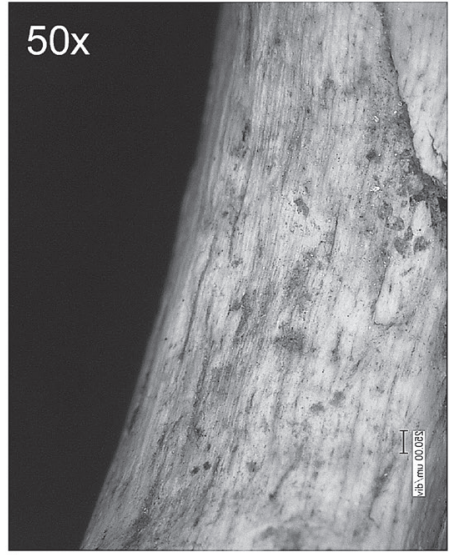

b

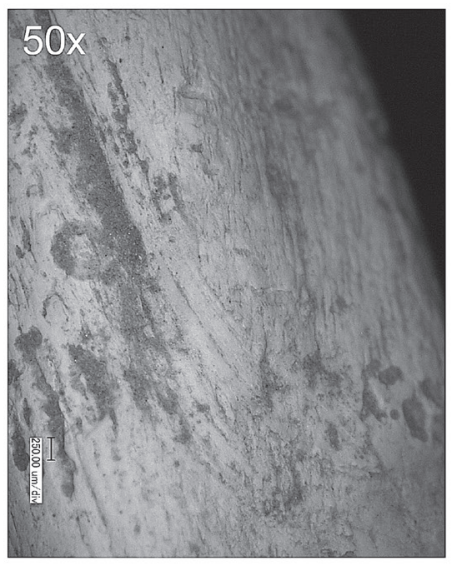

e

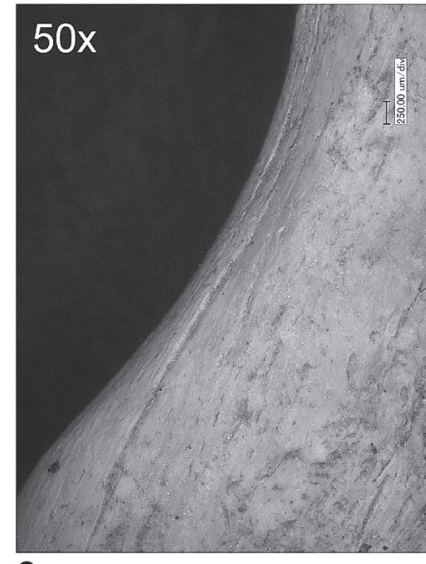

C

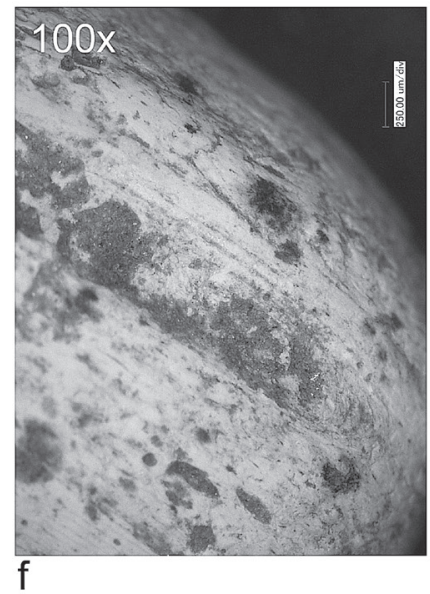

Fig. 9. Details of scraping marks on the surface of the specimens. Photo by M. Mărgărit

${ }^{39}$ Within the technological transformation scheme, the debitage and the shaping represent the two main operations. The debitage means any gesture for the production of a blank by division of the raw material. The second operation refers to the intentional action of shaping the selected blank regardless of the debitage method followed. For details, see: Averbouh-Provenzano 1999; Averbouh 2000 .
${ }^{40}$ It would have been important for this study if we were able to identify the type of tool used because experimental studies (see CHRISTIDOU 2008) suggest the presence of distinctive traces associated with the use of tools made from stone and bronze. Given the state of ornaments preservation is impossible to identify what type of tool was used but taking into account the age of these ornaments we can assume that items were processed with a metal tool. 


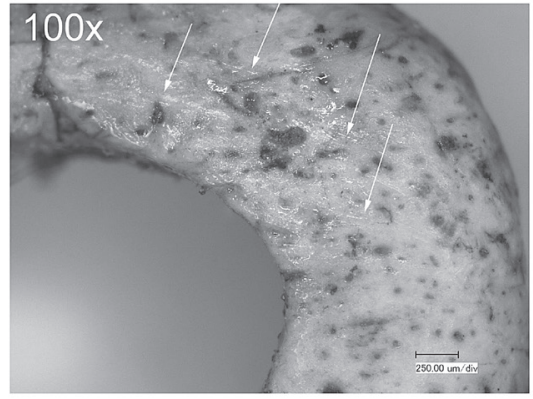

a

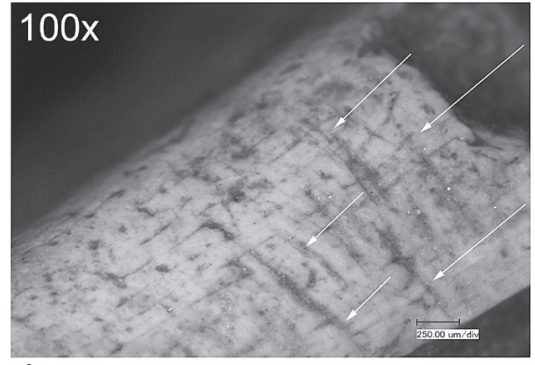

d

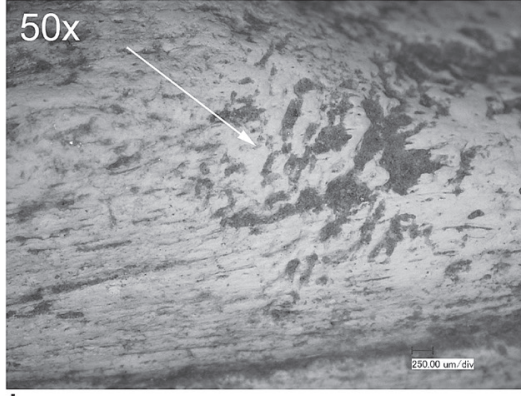

$\mathrm{b}$

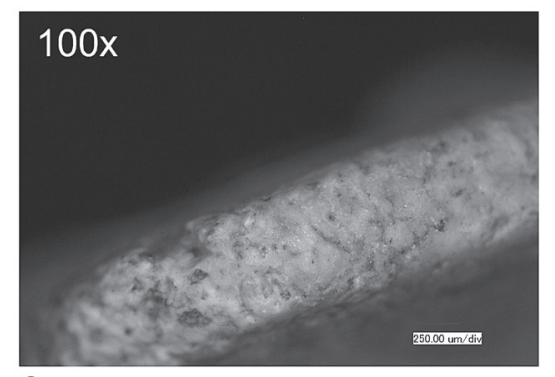

e

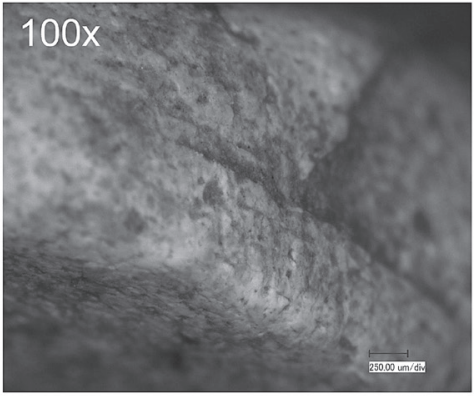

C

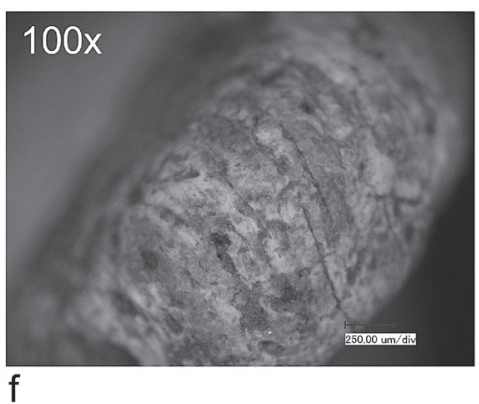

Fig. 10. Details of abrasion marks on the surface of the spcimens. Photo by M. Mărgărit

technological stage, the perforation procedure was carried out by rotation (Fig. 8d), the striae from this tehnique being difficult to identify because they were destroyed by the burning. The procedure applied was both unifacially (Fig. 8 e) and bifacially, depending on the individual specimen with the diagnostic element being the appearance of a ridge (Fig. 8f) inside the perforation.

Next came the shaping of the convex-concave morphology by longitudinal scraping at the mesial level. In the instances when the procedure left deeper marks or they were not destroyed by burning, we were able to identify them (Fig. 9a-c) as well as observe the finishing touches of the procedure (Fig. 9d). The globular shape of the proximal part was also defined by longitudinal scraping. Here, also the specific marks were visible only where the procedure left deeper marks (Fig. $9 e-f)$ in the raw material.

Final shaping was done by abrasion of the surface (Fig. 10a-c), the extremities (Fig. 10e-f) and, in one case, of the concave surface (Fig. 10d). More superficial than the scraping striae, the abrasion incisions were unfortunately the most difficult to identify as they were generally destroyed by the burning. It is unclear whether abrasion was applied to all the pieces or just to some.

There are two ways in which these items might have been used as decorative elements - either sewn onto clothes or suspended on a thread. If the beads had been strung together in composite ornaments, we should see marks resulting from the hitting of one piece against another, and an extended area of perforation deformation resulting from pressure generated hanging from a thread. If each individual bead had been sewn onto skins, leather or textile, we would expect to see different patterns of wear. First, one side of the bead would have been affected by rubbing against the material (e.g., flattening of the surface, modification of the external structure, macroscopic polish). Second, the deformation area developed on the wall of perforation would be more localized. The use-wear patterns observed on the archeological pieces seemed to correspond with this second mode of use. The functional marks show that, most probably, the ornaments imitating red deer canines were sewn onto the garments, the convex facet showing where the object rubbed against the leather or other clothing (Fig. 11d-f). The perforations (intact only on three items) exhibit a distortion of the initial shape that covered a small concave area at the distal extremity (Fig. $11 a-c)$ as a result of being were worn. 


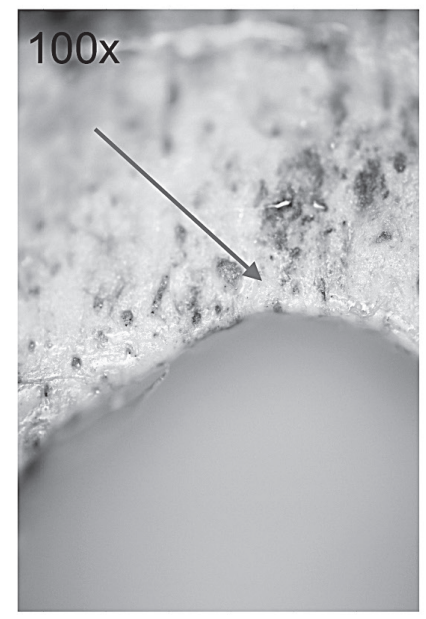

a

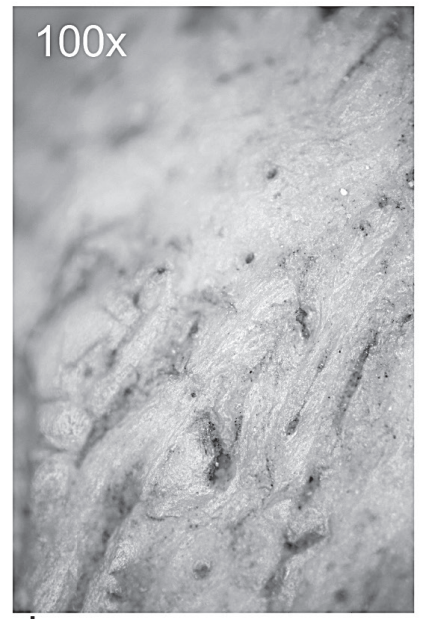

d

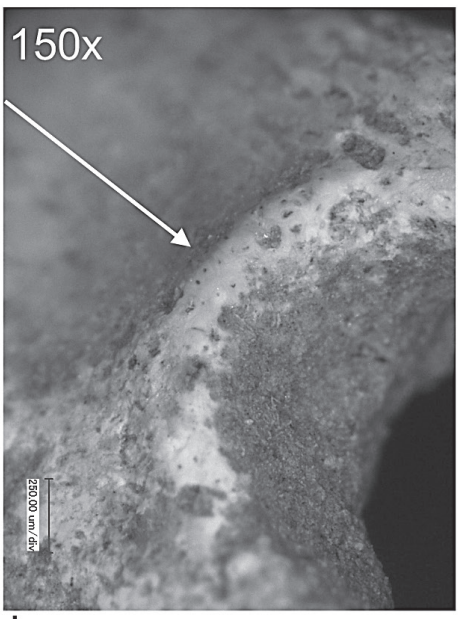

b

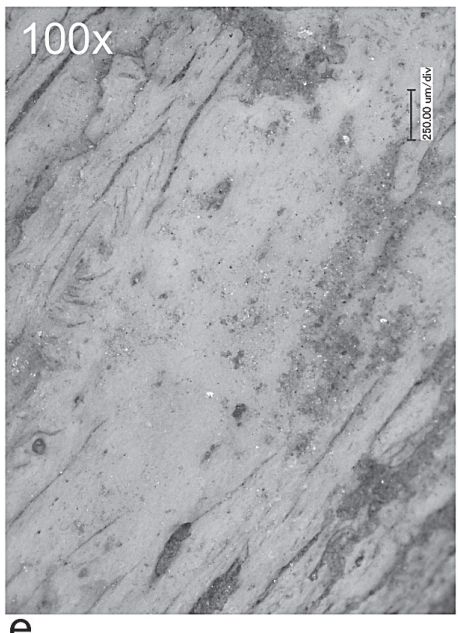

e

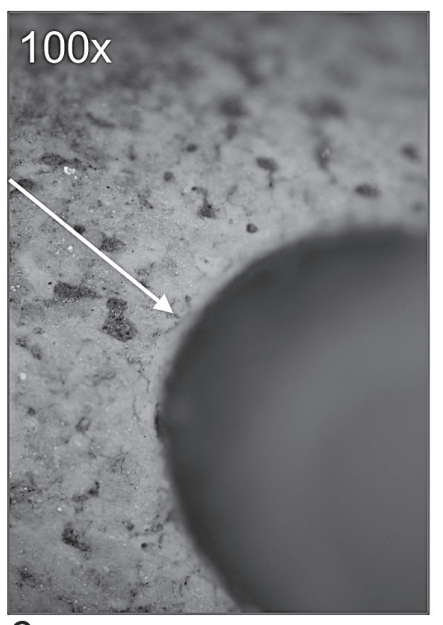

C

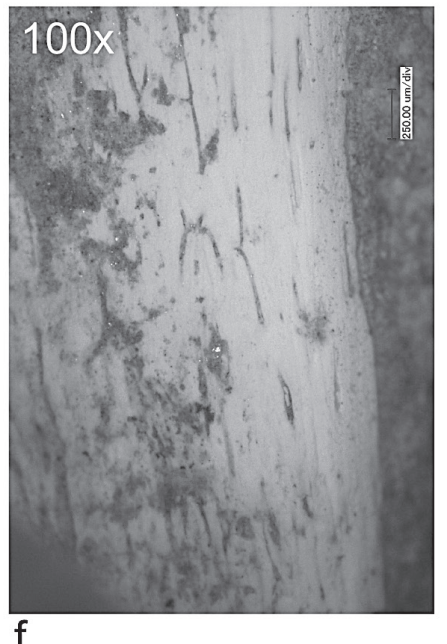

Fig. 11. Details of use-wear marks. a-c: deformation of the perforation; d-f. flattened surface. Photo by M. Mărgărit

\section{DISCUSSION}

Producing imitations of red deer canines seem to have been a significant custom of the Valea Stânii community. These teeth must have had a special meaning to the community that produced them and for the individual who was buried with them must have been a significant one since they were made of a raw material obtained from the same animal species - red deer. These artifacts are the single ones from the necropolis at Valea Stânii made of antler. As the corresponding settlement still remains unknown, where any traces of antler processing might have been documented, it is impossible to determine whether the choice of antler is related to the fact that it was a raw material at hand, a common, abundant, easy to obtain resource. Possible future research of a settlement belonging to this Early Iron Age group could clarify this issue, which has been left open for now. However, since in none of the archaeological sites attributed to the Ferigile group (there are hundreds of graves known) have been discovered so far artifacts made from antler, the choice of this raw material to work the canine imitations from Valea Stânii seems to be done not at random, but deliberately and more related to the significance of the animal itself.

The fact that the preserved perforations show signs deformation of the original shape from being worn indicates that these personal ornaments did not constitute a stricto sensu funeral inventory and they were not made for the unique purpose of being deposited in the grave. They were worn before that moment, either by the cremated 
person or by somebody else and were deposited as a funeral offering. The signs of use-wear appear to indicate that the pieces were sewn individually on the clothes.

Based only on the Valea Stânii artefacts presented here, we cannot determine precisely the importance of deer and deer hunting (possibly as a prestigious game species) in the Ferigile group's cultural milieu. The archaeological data (including the archaeozoological evidence) we have are scarce, disparate and not very conclusive. A number of observations, however, can be made. All data come exclusively from necropolises, as settlements of the Ferigile group are still almost unknown and as yet unexplored. Although red deer is absent from the animal offerings identified so far in graves (and whether it was hunted remains uncertain), some bones of mountaindwelling roe deer (Capreolus capreolus L. 1758) were reported from grave no. 9 in the tumulus 3 of the Tigveni necropolis, where a mature woman was buried. ${ }^{41}$ This is the only evidence of the use of game as a meat offering in Ferigile burials. Even in this case, game was not the only kind of meat offering, as it appeared alongside the body parts of other animals, all of them domestic (bird, calf, and caprinea). We may also note a few ceramic cups with zoomorphic handles, shaped like the head of roe deer (or possibly red deer (?): the prominent antlers are missing) found in some tombs, all identified in the important necropolises of the group, e.g. grave no. 1 in barrow no. 91 and the area of barrow no. 92 from Ferigile, ${ }^{42}$ barrow no. 17 from Tigveni, ${ }^{43}$ and also grave no. 23 in barrow no. 17 from Curtea de Argeș. ${ }^{44}$

It can be assumed that red deer, as an animal with exceptional traits and qualities, also continued to have a privileged symbolic position during the Late Iron Age, at least in the mythology of the Getae from the Lower Danube (as demonstrated by the majestic eight-legged deer represented on the silver goblets from the "princely" grave at Agighiol and also from the hoards of Rogozen and the Iron Gates, the three deer depicted on the silver helmet from another "princely" burial at Peretu, or a ceramic statuette found at the dava type settlement from Cârlomăneşti). ${ }^{45}$ Deer symbolism may also be found among the Celts in Central Europe (worthy of being taken into account is the worked deer skull fragment with broken antler found in the settlement at Sajópetri-Hosszú-dülö; also, the deer appears as a Cernunnos acolyte on the Gundestrup cauldron, and it may have the same kind of cultic representation, carved in wood, found on the ritual well at Fellbach-Schmiden) ${ }^{46}$ However, the mythological constructions and later artistic representations indicate that deer (and deer hunting) continued to be associated with high prestige and special symbolism among Balkan communities long after the time period represented by our artefacts. Signs of this continuation may include the myth of Herakles and the stag from Arcadia with ancestral origins, with from solid gold antlers and also the exquisite scenes of deer hunting displayed on some renowned monuments such as the "Alexander sarcophagus" from Sidon ${ }^{47}$ and the Gnosis' mosaic in the "House of the Abduction of Helen" in Pella. ${ }^{48}$ Furthermore, on the famous freeze of the Macedonian royal tomb from Vergina deer is represented among the four types of game reserved for royal hunts, along with lion, wild boar and bear. ${ }^{49}$

\section{CONCLUSIONS}

The imitations of deer teeth from Valea Stânii, in addition to their aesthetic value as rare and valuable items of adornment, constitute a manifest indicator of the transmission - in a general sense - and continuation of prehistoric traditions concerning status, prestige and display across several millennia, from the Upper Paleolithic throughout the successive periods until the late Early Iron Age in Eastern Europe. Therefore this rare and valuable find from the Early Iron Age may be considered a link in the chain transmitting and perpetuating the meaning and symbolic status of red deer until the dawn of Antiquity. This set of personal ornaments from Valea Stânii should be regarded as a revival of local traditions (or a borrowing of some other, more distant tradition) at the end of Prehistory. It is, however, not at all impossible that this revival was connected to cultural influences from the East, on the steppe. To get a full picture, however, of such interconnections, we must continue the research to find the missing links.

\footnotetext{
${ }^{41}$ NicOLAESCU-PlopşOR-WOLSKI 1975, 45, 100, fig. 10.

${ }^{42}$ VULPE 1967, 57, 161-162, pl. 5/26, 28.

${ }^{43}$ Popescu-VulPe 1982, 99, fig. 20/5.

${ }^{44}$ NANIA $1990,8-9$.

${ }^{45}$ SîRBU-FLOREA 2000, 97, 138-139, 142, 144, fig. 4, 6/c, $12 / 3,23 / 2 b, 57 / 2$.
}

Acta Archaeologica Academiae Scientiarum Hungaricae 70, 2019

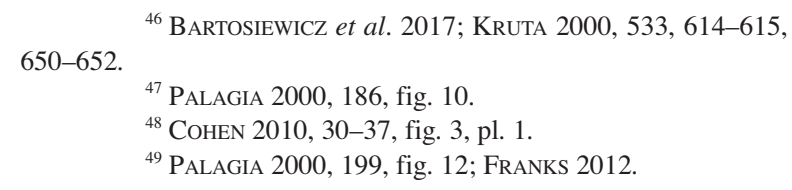




\section{ACKNOWLEDGEMENTS}

This work was supported by two grants of the Romanian Ministry of Research and Innovation, CNCS UEFISCDI, projects number PN-III-P1-1.1-TE-2016-0182 (Monica Mărgărit) and PN-III-P1-1.1-MC-2018-0371 (Dragoş Măndescu), within PNCDI III. Many thanks are due to Dr. Adina Boroneant (Romanian Academy) and to Dr. Alice M. Choyke (Central European University) for reading this manuscript, for the given suggestions and for improving the English translation. This paper is an extended version of the poster Un collier tardif d'imitations de craches de cerf découvert dans la nécropole de l'Age du Fer de Valea Stânii, département d'Argeş, Roumanie, delivered at the 18th World UISPP Congress, Paris, June 4-8, 2018.

\section{REFERENCES}

AVERBOuH 2000

AVERBOUH-PROVENZANO 1999

BÁNFFY 2008

BÁNFFY-BOGNÁR-KUTZIÁN 2007

BARTOSIEWICZ et al. 2017

BELDIMAN-SZTANCS 2008

BELDIMAN et al. 2012

BONNARDIN 2009

BUIKSTRA-UBELAKER 1994

CHILARDi et al. 2005

Choyke 2010

Christidou 2008

CoHen 2010

CRISTIANI et al. 2014

Čugunov 2005

FRANKS 2007

GiaCOBIni 2007

GRYAZNOV 1980

GRYAZNOV 1984
= A. Averboun: Technologie de la matière osseuse travaillée et implications palethnologiques. L'exemple des chaînes d'exploitation du bois de cervidés chez les Magdaléniens des Pyrénées. [Thèse de doctorat, Université Paris I.] Paris 2000.

= A. Averbouh-N. Provenzano: Propositions pour une terminologie analytique du travail préhistorique des matières osseuses. I.: Les techniques. Préhistoire Anthropologie Méditerranéennes (Aixen-Provence) 7-8 (1998-1999) 5-26.

= E. BÁNFFY: The deer tooth necklace from grave 12 at Bodrogzsadány. ActaArchHung 59 (2008) 163-169.

= E. BÁNFFY-I. BognÁr-KutZiÁn: The Late Neolithic Tell Settlement at Polgár-Csőszhalom, Hungary: the 1957 excavation. BAR IntSer 1730. Oxford 2007.

= L. BARTOSIEWICZ-A. M. ChOYKe-F. Reynolds: Stag do: ritual implications of antler use in Prehistory. In: The Neolithic of Europe. Papers in Honour of Alasdair Whittle. Eds: P. Bickle, V. Cummings, D. Hofmann, J. Pollard. Oxford 2017, 107-119.

= C. Beldiman-D.-M. SzTAnCs: Matière, artefact, symbole. Dents percées et imitations en os dans les dépôts d'objets de prestige de la culture Cucuteni. Studii de Preistorie 5 (2008) 89-107.

= C. Beldiman-D.-M. SzTAnCs-I. Cornel: Osseous Materials Artefacts in the Collection of History Museum Galati. Aeneolithic. Cluj-Napoca 2012.

$=\mathrm{S}$. BonNARDIN: La parure funéraire au Néolithique ancien dans les Bassins parisien et rhénan Rubané, Hinkelstein et Villeneuve-Saint-Germain. Societé Préhistorique Française, Mémoire 49. Paris 2009.

= J. E. Buikstra-D. H. UbelakeR: Standards for Data Collection from Human Skeletal Remains. Arkansas archaeological survey research series 44. Fayetteville 1994.

= S. ChILARDI-L. GuZZARDI-M. R. IovinO-A. Rivoli: The evidence of Spondylus ornamental objects in the central Mediterranean Sea. Two case studies: Sicily and Malta. In: Archaeomalacology Molluscs in Former Environments of Human Behavior. Ed.: D. E. Bar-Yosef Mayer. Oxford 2005, 82-89.

= A. M. Choyke: Red deer canine beads and their imitations. In: Crafting Bone - Skeletal technologies through time and space. Eds: A. M. Choyke, L. Bartosiewicz. BAR IntSer 973. Oxford 2010, 251-266.

$=$ R. CHRISTIDOU: An application of micro-wear analysis to bone experimentally worked using bronze tools. JAS 35 (2008) 733-751.

= A. CoHEN: Art in the Era of Alexander the Great. Paradigms of manhood and their cultural traditions. New York 2010

= E. CRISTIANI-I. ŽIVAlJEviĆ-D. Borić: Residue analysis and ornament suspension techniques in Prehistory: Cyprinid pharyngeal teeth beads from Late Mesolithic burials at Vlasac (Serbia). JAS 46 (2014) 292-310.

= K. V. ČUGUNOv: Kurgany ranneskifskogo vremeni mogil'nika Kopto i vopros sinchronizacii AldyBel'skoj i Tagarskoj kul'tur (Early Scythian barrows of the Kopto burial site and the synchronization of the Aldy-Bel and Tagar cultures). ASGE 37 (2005) 66-90.

$=$ H. M. Franks: Hunters, Heroes, Kings. The Frieze of Tomb II at Vergina. Princeton 2012.

$=$ G. GIACOBINI: Richness and diversity of burial rituals in the Upper Paleolithic. Diogenes 214 (2007) 19-39.

= M. P. GRYAZNOv: Arzhan. Tsarskij kurgan ranneskifskogo vremeni [Arzhan. The royal barrow from the Early Scythian period]. Leningrad 1980.

= M. P. GRYAZNOv: O monumental'nom iskusstve na zare skifo-sibirskih kul'tur v stepnoj Azii [On the monumental art at the dawn of the Scythian-Siberian culture in the Asian steppe]. ASGE 25 (1984) 79-82. 
GuZZo FALCI et al. 2018

HUDIAKOv et al. 2013

ILINSKAJA 1968

KAHLKE 2004

KEMENCZEI 2009

KRUTA 2000

LANGLEY-O'CONNOR 2016

MANNAI-Ool 1970

MARINESCU 1984

MĂNDESCU 2016

MĂNDESCU et al. 2017

MĂRGĂRIT et al. 2011

MĂRGĂRIT-DUMITRAȘCU 2017

Micheli-MAZZIERI 2012

MONAH 2003

NANIA 1990

NICOLAESCU-PLOPŞOR-WOLSKI 1975

NIESZERY 1995

ONORATINI et al. 2012

PAlAgia 2000

PATEK 2000

Petrenko 1978

PetTitT et al. 2001

PoPescu-Vulpe 1982
= C. GuZzo Falci-J. Cuisin-A. Delpuech-A. van Gijn-C. L. Hofman: New insights into use-wear development in bodily ornaments through the study of ethnographic collections. Journal of Archaeological Method and Theory 25/4 (2018) 1-51.

= Y. S. Hudiakov-S. G. Skobelev-O. A. Mitko-A. Y. Borisenko-Zh. Orozbekova: The burial rite of the early Scythian nomads of Tuva (based on the Bai-Dag I cemetery). Archaeology Ethnology \& Anthropology of Eurasia 41/1 (2013) 104-113.

= I. A. ILINSKAJA: Skify dnjeprovskogo lesostepnogo levoberezja [Scythians of the Forest-Steppe on the Left Bank of the Dnieper]. Kiev 1968.

$=$ H. D. KAHLKE: Sondershausen und Bruchstedt. Zwei Gräberfelder mit älterer Linienbandkeramik in Thüringen. Weimarer Monographien zur Ur- und Frühgeschichte 39. Weimar 2004.

$=$ T. KemEnCZEI: Studien zu den Denkmälern skythisch Geprägter Alföld Gruppe. IPH 12. Budapest 2009.

= V. KRUTA: Les Celtes. Histoire et dictionnaire - des origines à la romanisation et au christianisme. Paris 2000.

= M. C. LANGLEY-S. O'ConNoR: An enduring shell artefact tradition from Timor-Leste: Oliva bead production from the Pleistocene to Late Holocene at Jerimalai, Lene Hara, and Matja Kuru 1 and 2. PLoS ONE 11(8) 2016, https://doi.org/10.1371/journal.pone.0161071.

= M. Kh. MannaI-Ool: Tuva v skifskoe vremia (uiukskaia kul'tura) [Tuva in the Scythian Period (Uyuk culture)]. Moscow 1970.

= G. MARINESCU: Die jüngere Hallstattzeit in Nordostsiebenbürgen. Dacia N. S. 28 (1984) 47-83.

= D. MĂNDESCU: The necropolis from Valea Stânii (Argeș County) and a comparative approach to the Late Hallstatt Ferigile group features. In: Proceedings of the $15^{\text {th }}$ International Colloquium of Funerary Archaeology, Brăila, 20-22 May 2016. Ed.: V. Sîrbu. Istros 22. Brăila 2016, 153-180.

= D. Măndescu-M. Minalache-I. StănCulescu-M. Constantinescu: Contribuții la studiul pieselor de port și podoabă din mediul cultural Ferigile (Contributions to the study of the adornments from Ferigile cultural milieu). Peuce S. N. 15 (2017) 7-48.

= M. Mărgărit-M. Constantinescu-V. Dumitraşcu-A. BăLășescu: Obiecte din materii dure animale din aşezarea de epoca bronzului de la Năeni-Zănoaga Cetatea 2 (jud. Buzău) (Objects made of hard animal materials from the Bronze Age settlement of Năeni-Zănoaga Cetatea 2, Buzău County). Peuce S .N. 9 (2011) 15-54.

= M. MĂRGĂRIT-V. DuMITRAȘCU: Industria materiilor dure animale din așezarea de la Costișa (jud. Neamt) [The hard animal materials industry in the settlement from Costișa (Neamț County)]. In: Costișa - o perspectivă interdisciplinară. Ed.: A.-D. Popescu. Târgoviște 2017, 193-221.

$=$ R. Micheli-P. MAZZIERI: The circle and the square: steatite exploitation for personal ornaments manufacturing during the Middle Neolithic in northern Italy. Rubricatum. Revista del Museu de Gavà 5 (2012) 233-240.

= D. MonAH: Quelques réflexions sur les trésors de la culture Cucuteni. Studia Antiqua et Archaeologica 9 (2003) 129-140.

= I. NANIA: Necropola hallstattiană de pe câmpul Rodovanul de la Curtea de Argeş [The Hallstattian necropolis fom the Rodovanul field at Curtea de Argeş]. Studii şi Comunicări Muzeul Curtea de Argeş 3 (1990) 3-21.

= D. NiCOLAESCU-PLOPŞOR-W. WOLSKI: Elemente de demografie și ritual funerar la populațiile vechi din România [Elements of Demography and Funeral Ritual of the Ancient Populations of Romania]. București 1975.

= N. NIESZERY: Linearbandkeramische Gräberfelder in Bayern. IntArch 16. Espelkamp 1995.

= G. Onoratini-A. Arellano-A. Del Lucchese-P. E. Moullé-F. Serre: The Barma Grande cave (Grimaldi, Vintimiglia, Italy): From Neandertal, hunter of "Elephas antiquus", to Sapiens with ornaments of mammoth ivory. Quaternary International 255 (2012) 141-157.

$=$ O. Palagia: Hephaestion's pyre and the royal hunt of Alexander. In: Alexander the Great in Fact and Fiction. Eds: A. B. Bosworth, E. J. Baynham. Oxford 2000, 167-206.

= E. PATEK: A Szabó János Győző által feltárt „preszkíta” síranyag. A Füzesabony-Mezőcsát típusú temetkezések újabb emlékei Heves megyében (Die von János Győző Szabó freigelegten ,,preskythischen" Grabfunde. Die neuen Denkmäler der Bestattungen des Typs Füzesabony-Mezőcsát im Komitat Heves). Agria 25-26 (2000) 61-118.

= V. G. Petrenko: Ukrashenie skifii VII-III vv. do n. e [The Scythian Ornaments: The $7^{\text {th }}-3^{\text {rd }}$ centuries BC]. Moscow 1978.

= P. B. Pettitt-M. Richards-R. Maggi-V. Formicola: The Gravettian burial known as the Prince ("Il Principe"): new evidence for his age and diet. Antiquity 77 (2001) 15-19.

= E. Popescu-A. Vulpe: Nouvelles découvertes du type Ferigile. Dacia N. S. 26 (1982) 77-114. 
RIGAUD 2011

RIGAUD 2013

RIGAUD et al. 2015

SCHOLTZ 2012

SIKLÓSI 2004

SIDÉRA 1997

SÎRBU-FLOREA 2000

SVOBODA 2014

SZATHMÁRY 2011

TABORIN 2004

TÁTÁ et al. 2014

ToDOROVA 2002

UBELAKER 1980

VANHAEREN-D'ERRICO 2002

VANHAEREN-D'ERRICO 2003

VANHAEREN et al. 2013

Vitezović 2012

Vulpe 1967

VULPE 1990

VulPE-DrÂMBOCIANU 1981

WAHL 1996

WAHL 1996

WHITE at al. 2012
$=$ S. RIGAUD: La parure: traceur de la géographie culturelle et des dynamiques de peuplement au passage Mésolithique-Néolithique en Europe. [Unpublished Ph.D. Thesis. Université Bordeaux 1.] Bordeaux 2011.

= S. RigaUd: Les objets de parure associés au dépôt funéraire mésolithique de Große Ofnet (Allemagne): implications pour la compréhension de l'organisation sociale des dernières sociétés mésolithiques du Jura Souabe. Anthropozoologica 48 (2013) 207-230.

= S. Rigaud-F. D'ERrico-M. VANHAEREN: Ornaments reveal resistance of North European cultures to the spread of farming. PLoS ONE 10(4) 2015, e0121166. doi:10.1371/journal.pone.0121166.

$=$ R. Scholtz: Scythian Age burials at Tiszalök. In: Iron Age Rites and Rituals in the Carpathian Basin. Proceedings of the International Colloquium from Târgu Mureş, 7-9 October 2011. Ed.: S. Berecki. Târgu Mureş 2012, 77-100.

$=$ Sz. SiKLósi: Prestige goods in the Neolithic of the Carpathian Basin. Material manifestations of social differentiation. ActaArchHung 55 (2004) 1-62.

= I. SIDÉRA: Le mobilier en matières dures animales en milieu funéraire Cerny: symbolisme et socioéconomie. In: La culture de Cerny. Nouvelle économie, nouvelle société au Néolithique. Actes du colloque international de Nemours, 9-10-11 mai 1994. Ed.: C. Constantin, D. Mordant, D. Simonin. Mémoires du Musée de préhistoire d'Ile-de-France 6. Nemours 1997, 499-513.

= V. SîrbU-G. Florea: Les Géto-Daces. Iconographie et imaginaire. Cluj-Napoca 2000.

$=$ E. SvodobA: Artefacts from organic materials in Neolitihic graves: selected cases. Studia Archaeologica Brunensia 19 (2014) 5-21.

$=$ L. SzATHMÁRY: Scythian Age human skeletal remains from Tiszalök. In: Iron Age Rites and Rituals in the Carpathian Basin. Proceedings of the International Colloquium from Târgu Mureş, 7-9 October 2011. Ed.: S. Berecki. Târgu Mureş 2012, 101-104.

$=$ Y. TABORIN: Langage sans parole. La parure aux temps préhistoriques. La maison des roches. Paris 2004.

= F. TÁtá-J. Cascalheira-J. Marreiros-T. Pereira-N. Bicho: Shell bead production in the Upper Paleolithic of Vale Boi (SW Portugal): An experimental perspective. JAS 42 (2014) 29-41.

$=$ H. Todorova: Grandeln, Hirschgeweih, Eberhauer aus den Gräberfeldern von Durankulak. In: Durankulak. 2.: Die prähistorischen Gräberfelder von Durankulak. 1.T. Ed.: H. Todorova. Sofia 2002, 187-190.

= D. H. UBELAKER: Human Skeletal Remains. Washington 1980.

= M. VANHAEREN-Fr. D'ERrico: The body ornaments associated with the burial. In: Portrait of the Artist as a Child. The Gravettian human skeleton from the Abrigo do Lagar Velho and its archeological context. Ed.: J. Zilhão, E. Trinkaus. Trabalhos de arqueologia 22. Lisboa 2002, 154-186.

= M. VANHAEREN-Fr. D'ERRICO: Le mobilier funéraire de la Dame de Saint-Germain-la-Rivière (Gironde) et l'origine paléolithique des inégalités. PALEO 15 (2003) 195-239.

= M. VANHAEREN-F. D'ERrico-K. L. van NieKerK-C. S. Henshilwood-R. M. Erasmus: Thinking strings: additional evidence for personal ornament use in the Middle Stone Age at Blombos Cave, South Africa. JHE 64 (2013) 500-517.

= S. ViTEZović: The white beauty - Starčevo culture jewellery. DocPraehist 29 (2012) 215-226.

= A. VulPE: Necropola hallstattiană de la Ferigile - Monografie arheologică [The Hallstattian Necropolis from Ferigile - Archaeological monograph]. Bucureşti 1967.

= A. VulPE: Die Kurzschwerter, Dolche und Streitmesser der Hallstattzeit in Rumänien. PBF VI/9. München 1990.

= A. VulPE-V. DrÂMBocianu: Cercetări arheologice în raza comunei Năeni (Buzău) [Archaeological researches in Năeni commune (Buzău county)]. SCIVA 32/2 (1981) 171-193.

= J. WAHL: Erfahrungen zur metrischen Geschlechtdiagnose bei Leichenbränden. Homo 47/1-3 (1996) 339-359.

= J. WAHL: Investigations on pre-Roman and Roman cremation remains from southwestern Germany: Results, potentialities and limits. In: The Analysis of Burned Human Remains. Eds: C. W. Schmidt, S. A. Symes. Cambridge, MA 2008, 145-161.

= T. D. White-M. T. Black-P. A. Folkens: Human Osteology. Cambridge, MA 2012. 